ACTA UNIVERSITATIS LODZIENSIS

FOLIA LITTERARIA POLONICA 8(38) 2016

http://dx.doi.org/10.18778/1505-9057.38.08

Maria Berkan-Jabłońska*

\title{
Poetic Lithuania of Miłosz
}

"But the moment of memory is unbeatable. In the middle of the night it returns. Who is holding the torches, That what had been is happening in the light again?" (Master)

"Lithuania is the beginning and Lithuania is the end" - stated Czesław Miłosz in his youthful work, and he entitled one of his last poetic series Lithuania after 52 years. In spite of his repeated declarations of dislike towards autobiographism in literature, the land of his childhood accompanied the author in all of his literary output. Occasionally the fascination with Lithuania revealed itself in a diligently reconstructed genealogy of the Miłosz and Syruć houses, searching for traces of local legends, indulging in even minor traces of the past, sometimes in a basic delight over the beauty of the lands praised for centuries.

In the sketch $L a$ Combe, dedicated to an unusal Hucul, the poet wrote:

Vincenz knows that people miss their fatherland nowadays, but instead of it they are given only countries. Homeland is organic, grown into the past. It is always small, heart-warming, close as own body. Country is mechanical. Homerand is Wales, Brittany, Provence, Catalonia, Basque Country, Transylvania, Hucul land ${ }^{1}$.

Hearing these words makes us look onto his poetical images of Lithuania as a symbol of inner - and not only geographical - settlement. On the one hand, it is formed by the connections of Miłosz's literary output and his literary predecessors from the so-called Lithuanian school - especially Mickiewicz, on the other hand, they can be seen from a broader perspective as an element of the spiritual adventure of a human being, a journey "to the centre, to Ithaca, meaning to the inner part of oneself"

\footnotetext{
* Dr hab., University of Lodz, Faculty of Philology, Institute of Polish Philology, Department of Romantic Literature; e-mail: m.berkanjablonska@interia.pl.

${ }^{1}$ C. Miłosz, La Combe [Foreword to: S. Vincenz, Po stronie pamięci], Instytut Literacki, Paryż 1965, p. 9.

${ }^{2}$ M. Eliade, Religia, literatura i komunizm, in: Dziennik emigranta, transl. A. Zagajewski, Puls, London 1990, p. 220.
} 
A changing look onto Lithuania corresponds with the particular life stages of the hero's journey in Miłosz's poetry. The initial Arcadian vision of "a small homeland" is a direct reaction to the first hardships of facing an outer world. A deepened reflexion over the phenomenon of exile - the emigration started, according to the poet, when he left Vilnius in 1937 - gradually modified this ideal image of his childhood land. An awareness of being burdened with the fate of eternal Ulysses, interwoven with an unfavourable political situation, creates the need to "amputate" the Kresy heritage. It was only after years of searching that led to a renewed appreciation and usage of this heritage, but this time in a changed, more symbolic form ${ }^{3}$.

It is worth noticing that the literary context Lithuania was set in gave way to eschatological considerations with time. Real images of Kresy were gradually connected with a narration of human helplessness in the face of transition and the fight against annihilating memory, emptiness and the inability of becoming established in the world. All these feelings, provoking questions about the sense of existence, shaped a more and more mature contemplative attitude and restore the metaphysical dimension of human existence.

Lithuania turned out to be a peculiar compass that marked out the most important moments in the journey to self-awareness and knowledge. "With this land one can love a lot" - confessed Stanisław Witkiewicz (father) once ${ }^{4}$.

\section{My Lithuanian amputation is painful}

An attachment to the homeland is typical of everybody. However, the twentieth century was not favourable to settled lifestyle, on the contrary - repeatedly in our century one left safe homelands to look for the shelter amongst other people and in other places. A growing number of emigrants seemed to confirm the image of humankinds biblical wandering, after Adam and Eve being driven out from the Paradise. The awareness of being introduced into the rhythm of universal exile does not mean resignation from the attempt to define one's own place in the world, deliberately organizing space to overcome the hopeless emptiness of the first moments in exile.

In Lost places Czesław Miłosz, undoubtedly influenced by the thought of Simone Weil, wrote:

${ }^{3}$ The attitude of the persona towards Lithuanian heritage can be described with the formula of trinity by William Blake: a time of innocence, a time of fall, and a time of restored innocence. This theory was analysed by C. Miłosz, among others, in Ziemia Ulro, Państwowy Instytut Wydawniczy, Warsaw 1982 and idem, Świadectwo poezji. Sześć wykładów o dotkliwościach naszego wieku, Czytelnik, Warsaw 1987.

${ }^{4}$ As cited in: B. Wachowicz, Ty jesteś jak zdrowie, Rytm, Warsaw 1993. 
establishment is a permanent need of human nature. It can be connected somehow with laws of human system, and strictly speaking with laws of nature [...] The change of environment causes disturbance of the rhythm and big expense of energy on going to new rhythm [...] Settlement then would be innate and become widespread in this century the fate of the exiles would mean for people disturbance of natural order ${ }^{5}$.

It seems that for a majority of Polish poets-emigrants, even Kazimierz Wierzyński or Jan Lechoń, such original centres of space lie in Poland, its tradition or individual or collective past connected with it, as well as the images and memories which were the sources of their output:

It is not skillfulness of a hand

I write the poetry but waters, trees

and sky, so beloved to us even the dark

which were seen by our parents, parents of our parents

and their parents' parents, from the primeval

- Miłosz confessed in Lauda. For the author of Issa Valley - as he mentions - the exile started with his trip to Warsaw in 1937.

In my homeland, where I will never come back

There is a forest enormous lake

- he described Lithuania, his homeland, but also an exceptional vocation:

I am bending over and I can see there down

The shine of my life

The beginning of the poem When the sun rises and when it sets in develops this thread of being written in the provinces of destiny, a call to the eternal poet's difficulty and overcoming the boundaries of time and space, the necessities of History and ordinary human weaknesses.

Despite the emphasized importance of Lithuanian experiences and Miłosz's frequent return to them in poetry, granting the Valley of Niemen and Niewiaża or Vilnius the role of the only or the most important settlement centre would be a simplification.

It is not without a good reason that the problem of fidelity and infidelity of Lithuania come up again and again in Miłosz's literary output and it is a sign of doubts, which touched this poetry and its author.

\footnotetext{
${ }^{5}$ C. Miłosz, Miejsca utracone, in: idem, Szukanie ojczyzny, Znak, Cracow 1992, p. 189.
} 
"Who were I? Who am I after years, here on the Bear Peak, in my studio at the Pacific?" - a man with a precise, clear vision of the world does not struggle with such doubts, having confidence in its order.

What is more, the first volume published in exile, The Light of Day, surprised with its reluctant attitude towards the past - also those poems connected with youthful experiences or acquaintances from the Borderlands. When Vladimir Nabokov wrote:

"Mojej rozpaczy wspominania

Przysięgam po królewsku strzec"
["My despair of remembering

I swear to guard like kings"]

Miłosz in these poems expressed different moods. He depended on memory and susceptibility to drop off and stifle the memories - treating it as destructive to the artist. He rejected an idealized memory of Lithuania - emphasizing its provinciality and, according to the writer's epithet, its "fossilization"7. This critical view of the land of adolescence is accompanied by a gradually changing way of perceiving Europe and America.

It is quite clear that in this volume in the face of the war and post-WWII experiences the attempts at declaring the identity of European and the further meaningfulness / sense of the civilization built here by thousands of years are more important than interest in the past. The poem Child of Europe includes a perverse image of an inhabitant of our continent who forgets about his roots and the values which he was brought up with for an easier life. The lack of ethical sensitivity of the contemporary world is underlined clearly, which points out the disproportionate human moral development and his cultural vitality, whose external remains are gothic cathedrals, baroque churches, synagogues, Cartesian philosophy, terms such as "honour" and "justice". This captured European heritage - reduced to non-significant images and terms - did not protect and will not protect humans from the catastrophic results of its nature contamination, means nothing in comparison with the presence of the $1950 \mathrm{~s}^{8}$. What could replace or have a bearing on one's future and small provincial Lithuania?

Nie kochaj żadnego kraju: kraje łatwo giną

Nie kochaj żadnego miasta: łatwo rozpada się w gruz

Nie przechowuj pamiątek, bo z twojej szuflady

${ }^{6}$ C. Miłosz, Ziemia Ulro, p. 21.

7 "fossilized" ("zaskoruzła" transl. footnote) means, according to the poet, behind the times, barbaric (See Czestawa Miłosza autoportret przekorny, interviewed by A. Fiut, Wydawnictwo Literackie, Cracow 1988.

${ }^{8}$ Criticicism of European cultural heritage did not preclude the attempt at searching settlement in Europe. Such attitude of Miłosz towards the West, that is his defense and at the same time fight with him, Gombrowicz: "I feel the same, which lies in me, this is dislike and disregard in relation to them mixed with bitter helplessness" (See W. Gombrowicz, Dzienniki 1953-1956, Wydawnictwo Literackie, Cracow 1989, p. 24). 
Wzbija się dym trujący dla Twojego oddechu

Nie patrz w jeziora przeszłości: tafla ich rdzą powleczona

Inną ukaże twarz niż się spodziewałeś.

[Do not love any country: they die out easily

Do not love any city: easily falls apart in debris

Do not keep souvenirs, because from your drawer

Stirs up the poisonous smoke for your breath

Do not look in lakes of the past: their sheet is covered with rust

Will show a different face that you expected]

Needless to say, this poem is ironic, and it should not be read literally. However, one cannot help but feel that it was inspired by a bitter conviction of the topicality of this model in then contemporary Europe.

When in Portrait from the middle of $20^{\text {th }}$ century Miłosz wrote about its ordinary inhabitant:

Dawne wiary w nim nie zagasły. Czasem myśli, że jest we władzy demonów. Gromi przeszłość, bojąc się, że kiedy ją zgromi, nie będzie miał gdzie złożyć głowy

[Ancient faiths fade away in it. Sometimes he thinks that he is in the power of demons. Blasts the past, being afraid that when he blast it, there will be no place to make his head]

- it was as if he had disclosed the illness which affected him, the poet, Lithuanian and Pole in one person. These words are a perfect commentary on the creative output of the author of Captive Mind during this period. In many poems of this period, a strong endeavour is made to break off the connection with the past against both of these "non-faded away faiths".

Such a painful attitude to past times and places is composed of many sources the already mentioned acceptance of the European perspective and in this way the rejection of Vilnus and Szetejna provincialism, conflicts with the emigration community, and the poet's fear of trivial sentimental jingoistic memories.

He touched this problem in a moving way in the poem entitled In remembrance of Teresa Żarnower. The poem - touching on the tragedy of a neglected and abandoned woman - "without neither friends nor relatives, in a big, big city". It is Washington or New York, or simply any of the American whoppers, where one lives "in the lines of hundred floors", in complete oblivion or a fight for success. Whereas such a life, for almost every person from the Old Continent, and for consolidated pre-war Warsaw or small Vilnus - still lasting after years of dying. Haven for the agonized is found only in the news from the ocean, news from the country - paradoxically - also striking and destroying any hope: 
A wieść każda co do niej przez ocean biegła

O wygnanych, otrutych, za życia spalonych,

Była jak znak ostatni - i świat ją pożegnał

I nie było ucieczki od lat utraconych

[And every piece of news which through the ocean was running to her

About exiled, poisoned, burnt alive,

She was as the last sign - and the world farewelled her

And there was no escape from lost years"]

The description of the personal tragedy is connected in this poem with the question of the past's primacy over the present. The death of titled Teresa Zarnower is also the death of an emigrant, who in in her new surroundings could not accept herself.

"The old trees are not moved" - the old proverb says. The poet refered to the symbolic image of the tree as well:

Aż jak sosna rumowisk w burzy pod ulewą

Stała w świetle neonów, smutne, czarne drzewo

[As the pine of rubble under downpour

Was standing in the light of neons, sad, black tree]

Without an agreement for a new place, in a constant thought of "exiled, poisoned, burnt alive" died because "he wasn't strong enough / to defeat the Past with cooling hand". It is an awkward and striking conviction of the writer which in the expression of the exile towards the past sees the source of a threat. It does not mean the consequences of this attitude, among others death, but instead the model of life resulting from it.

Miłosz in a special way seemed to be afraid of History’s power, Lithuanian reminiscences, and through them, being identified with and absorbing their provinciality and limitations. Wojciech Karpiński rightly noticed that Gombrowicz had a similar attitude towards emigration as Miłosz. In The Land of Ulro Miłosz admitted:

Dwaj emigranci przez polską emigrację piołunem karmieni, dopóki nie dowiedziała się od cudzoziemców i przybyszów z Polski, że jesteśmy coś warci, sobie wzajem świadczyliśmy przyjaźń ${ }^{9}$

\footnotetext{
${ }^{9}$ C. Miłosz, Ziemia Ulro, p. 30
} 
[Two emigrants by polish emigration bed with wormwood, until she does not know from the foreigners and newcomers from Poland that we were worth, we performed friendship each other].

It was not the criticism of the values represented by this community but the forms, patterns, stereotypes, which - as it was noticed - were yielded to.

When the holidays come - wrote Ferdydurke's author in Diary - you like water with tears the flower bed of memories and sight dolefully to the lost homeland. Don't be ridiculous or sentimental! Learn to carry your own destiny [...] What does it mean that you don't live in Grodno, Kutno or Jedlińsk? Has ever a man stayed somewhere else than in himself? You would be at home even if you were in Argentina or Canada because homeland is not a place in the map but alive being of a $\operatorname{man}^{10}$.

Both writers were aware of the fact that exile gave opportunity to emigres because it forced constant effort and work on oneself, struggles with creative impotence, sudden loss of readers and writing habits. Finally, the exile mobilizes one to overcome the fear of tightly holding on to a well-known past, encourages the full use of the achieved independence. "Loss of homeland won't throw in anarchy only this one who can reach deeper, outside the homeland, for whom the homeland is only one of the revelations of eternal and universal life. Loss of homeland won't disturb the internal order of those whose homeland is world"11.

Gombrowicz, like Miłosz, always came out against closing the writer within the confines of particular, national literature, which would make his artistic development impossible. Especially for Miłosz, the first years in exile were weighted down with the sense that the heritage of Lithuania and Poland was threatened, and a fight with his own weaknesses and blindness. The attempt at "amputating Lithuania" was given sometimes a poetic vent in painful and not very ambitious satire - like striking at the political, post-war attitudes of former buddies from Vilnus. It is at the same time a revision of the intellectual and patriotic tradition of the $19^{\text {th }}$ and $20^{\text {th }}$ centuries, still alive in Lithuania, settling scores with that - according to the poet - old-fashioned and provincial upbringing:

\footnotetext{
${ }^{10}$ W. Gombrowicz, Dzienniki..., p. 95.

${ }^{11}$ In this meaning one can mean the closeness of creation intentions, for example Trans-Atlantyk and reference to the native culture and tradition of the poems from String of Light. What is the most important is the overcoming of certain common phraseology. "Through Poland of 1939" Trans-Atlantyk goals at every past and present of Poland because I mean overcoming the national form as such, elaborating the distance to any "Polish style". That was what Marcin Król meant, who placed Miłosz and Gombrowicz in the guide of opponents of symbolic Zbaraż. (See M. Król, Podróż romantyczna, Libella, Paris 1986, p. 8).
} 
Rośliśmy nieświadomi w naszym cichym mieście

Oddalone jest od nas o lat chyba dwieście

[We were brought up in our quiet city

Remote from us about two hundred years]

Just as in his memories of Vilnus, Janusz Dunin-Horkawicz saw:

We lived in the borderline of eastern and western cultures, in the corner of Europe, where as well West as East came last, where not only in the countryside and forests ancient and Central European familiarity was flickering. Even at the turn of the thirties, when the scholars were pondering the breaking of the atom, here the peasants brought an elf-lock to the hospital which they defended in the conviction that cutting it off means blindness. [...] Even the intelligentsia looked here sceptically at the development of science ${ }^{12}$.

A sense of superiority towards different nations ("Local man, opened and hospitable can be mistrustful and closed, when he treated somebody as an alien. Particular national groups created closed worlds and if there is an osmosis, it was for rubbing in the street" - J. Dunin-Horkawicz), provinciality, in which one does not appreciate what is valuable, "fear of thinking", a book, attachment to the conventionalities and stereotypes - these were only a few negative sides of the Borderlands heritage described by Miłosz ${ }^{13}$.

Almost all the poems of this period recalling any images of Lithuania strike us with their dislike and scorn. I have the impression that the laugh of Gombrowicz simplifies less the attitude towards tradition and native roots than Miłosz's poetry of this time. Thus, instead of the charge of simplification pretending would be more justified here. Since beside the concrete words of criticism, often assurance happens that suggests that recalling images of the past is for a poet (?), his poetical alter ego (?) impolite:

Lecz między nami mówiąc, ta wsławiona ziemia

Żeby tam mieszkać, była już nie do zniesienia

Absurd można wytrzymać, jeżeli jest w miarę

Tam jednak był nie jeden i nawet nie parę

I przyznam się, że nie mam teraz jakoś chęci

Tamte senne obrazy wywlekać z pamięci.

${ }^{12}$ J. Dunin-Horkawicz, Co było a nie jest... czyli kilka lat młodości mojej w Wilnie, Poprzeczna Oficyna, Łódź 1985, p. 3.

${ }^{13}$ One should point out that Miłosz was then attracted to a mythic image of Lithuania, and criticized first of all Polish influences, specified often as in a limited way as nationalistic. 
[But just between ourselves, this famous soil

In order to live, was unbearable

Absurd one can bear if it is moderated

However, there was more than one and even not a pair

And I will admit that I don't fancy

These drawsy images drag out from memory]

In the poem On bird's song on the shores of Potomak he added: "What do I need go in these dark places".

In his postwar and occupation output the poet struck the pose of a romantic bard, painting with ideal colours the valley of Niemno and Nieważa. Here, however, a public debate with Mickiewicz seems to be very clear. Analogous situations such as - distance towards Lithuania and events from the youth, return in memory to the past years - are deprived of romantic sentiment, warmth and familiar patriotism. Dried tears and the seduction of the smallest - these are Sir Thaddeus was boiled down to. To the famous call:

Tymczasem przenoś moją duszę utęsknioną

Do tych pagórków leśnych, do tych łąk zielonych

[In the meantime take my longing soul

To these green hills, to these green meadows]

The persona answers:

Wybacz mi proszę, brak tego wzruszenia

Które prowadzi przemocą z powrotem

W miejsce i wiosny dawno zapomniane.

[Forgive me please, shortage of this emotion

Which leads again with violence

In place and spring long ago forgotten.]

In the meantime such declarations do not go together with following Lithuanian habits, friendly games, well-known corners. These steps remind the readers of the satire On the King of the little master Krasicki: "Let we write one thing and read a different one".

What is more, in both poems - Toast and On bird's song... - it is puzzling the discrepancy in showing the borderlands world. I compare several chosen fragments: 
Mnie to niemiłe. Po cóż mi wspominać [It is unpleasant for me. Why should I recollect

Żółte od liści młodziutkich Ponary Yellow leaves of the young of Ponara Zapach wilczego łyka migdałowy, smell of wolf gulp almond,

Echa po lasach od wrzasku cietrzewi?

Echoes in the forests from the black grouse's squawk?

Po cóż mi znowu iść w te ciemne sale Why should I go again in these gloomy classrooms

Gimnazjum króla Zygmunta Augusta Albo o sosny potrącać biczyskiem King Sigismund Augustus Junior High School or pines knocked over by a whip

$\mathrm{Na}$ drodze z Jaszun, jak ongi Słowacki?

On the way from Jaszuny, as once Słowacki?

Nad Mereczanką nasze to zabawy Były czy dworzan króla Władysława, Nasze miłości i nasze rozstania By the Mereczanka these are our games Were or the king's Ladislaus courtiers, Our loves and our partings Czy też miłości z pieśni Filomatów, Już nie pamiętam [...]

\section{(Na śpiew ptaka nad brzegami Potomaku)}

Or loves from the Philomaths song, No longer I remember [...]]

(On bird's song on the shores of Potomak)

Jednak niekiedy, z rzadka tak mi się wydarzy

Kiedy ja, rad, że lekcja nie była zadana, Idę czytać podróże do Tomasza Zana Nie troszcząc się o wieszczów, szliśmy na wagary,

Tam mniej więcej gdzie oni, a więc na Ponary

Na urwiska Zakrętu. W niedzielne poranki

Jeździliśmy do Jaszun, nad brzegiem Mereczanki,

Tęskniąc do nadzwyczajnej, dalekiej przygody

Do stolicy, do siostry Jurka - i do brody.

Nie spotkałem już nigdzie takiego baroku, Takich wód przezroczystych i takich obłoków

[However sometimes, rarely it happens to me

When I, happy, that the homework wasn't given

I am going to read Tomasz Zan's travels not caring about poets, we played truants,

There more or less when they, that is to Ponary

to Zakręt precipice. In Sunday mornings

we went to Jaszuny, by the shore of Mereczanka

Missing remarkable, distant adventure

To the capital, to Jurek's sister - and to the beard.

I have never met such baroque, such transparent waters and such clouds 
a także takich dziwactw

i staroświecczyzny,

która tam uchodziła za symbol ojczyzny.

(Toast) and also such oddities and old-fashion

which there passed as a symbol of homeland.]

(Toast)

From all these supposedly remembered details, only those are revealed that are marked with history or literary tradition and certified with the presence of a few generations. Along with the remembrance of Lithuania there appears in the eyes of these poems a memory of passing ages connected with the presence, passing away people, eternal spirit of History.

When we say history, instinctively we mean the past - Alan Nevins has pointed out - and this is a mistake because history is a platform combining the past and the presence, at the same time defines direction aiming at the future ${ }^{14}$.

In front of our eyes a special map of Vilnus and its surroundings is being sketched: "Winding, narrow streets, Wilia and Wilenka, riverside gardens - don't have in this view a Renaissance or Classicistic regularity, and a picturesque charm it owes numerous towers and domes of Baroque churches"15. It is not difficult to point out King Sigismund Augustus Junior High School on a map. Miłosz’s poem is radiant as well with the atmosphere of school years as a peculiar patronage of Grand Duchy of Lithuania as co-author. This is a portrait of the last Jagiellonian, hung in auditorium of junior high school, reminding us of the bygone Grand Duchy of Lithuania rank. "Gente Lithuanus, natione Polonus" - as the Issa Valley author used to say. A little further spread the sites by the Mereczanka, where the poet's peers carried on their games, and before them many hundreds years earlier the protagonists of Sarbiewski's Silviludia. Having fallen in love, Słowacki wandered there in 1826; here also in the palace of Śniadeccy, he passed his last Christmas in the Vilnius Region. How easy it is to find or listlessly even keep repeating excesses of young Philomates. Indeed, the times do not change the picnics, truants in Ponary, discussions, dreams or affairs.

Nevertheless, for Miłosz history had an ominous significance. So, this historicity of Lithuania, captured in a brace of "unpleasant" recalling, is set against the symbolic song of a bird by the shore of an American lake. The bird seems to embody the miracle of the eternal and constant lasting quality of Nature, which exists without time and suffering, without the necessity of pardoning them with

\footnotetext{
${ }^{14}$ As cited in: W. Łysiak, Milczace psy, Krajowa Agencja Wydawnicza, Cracow 1990, p. 31.

${ }^{15}$ A. Kowalczykowa, Wileńskie fascynacje, czyli o barokowej młodości Juliusza Stowackiego, "Ruch Literacki" 1988, a.6 (171), p. 403.
} 
falsity of souvenirs or theories, only influenced by the constant laws of biology, genre evolution. Hence, it is the dream of the artist - "My home - a second: in it the beginning of the world" - in order to even in a fleeting associativity with Nature find peace and possibility of taking its roots:

Moją stolicą bobrowe żeremie

I sfałdowała się jeziorna woda,

Orał ją w kółko czarny księżyc zwierza

Wzeszły głębiny, z bulgotu metanów

Niematerialny nie jestem, nie będę
[Beaver's lodge is my capital and the water of lake was creased, plought again by the black moon of a beast Rose the depths, from guggling of methane I am not immaterial, I won't be so incorporeal glare isn't for me Mój odór wspólny, mój odór zwierzęcy, My common stench, my animal stench, Mieni się tęczą, bobra spłoszy

I klaśnie echo sparkles with a rainbow, will scare the beaver And the echo will clap.]

- We can read in Poetic Treatise.

To America in 1945 he went - as it seems - not as a diplomat, but a lover of Tomasz M. Reid and James Cooper's novels. The new world was treated rather as a romantic land of magic, "fulfilment of childhood legends about thicket core". A charming but literary image which could not survive the confrontation with the reality.

$\begin{array}{ll}\text { W różowych palcach magnolii } & \text { [In purple fingers of magnolia } \\ \text { W puchu pięknego maja [...] } & \text { In the fluff of beautiful May [...] } \\ \text { Leży to miasto } & \text { There is a city } \\ \text { W które wjeżdżam z bukietem } & \text { Where I drive into with a bouquet } \\ \text { sztywnych róż } & \text { of rigid roses] }\end{array}$

- Miłosz described in Journey his first impressions. However, very soon the dominating body became a feeling of the morbid sterility of this "virtual land". It is difficult to delight with the whirling mass of bodies in Central Park or an ice skating girl from the text There is no sight. They show radical depersonalization, loss of human identity, moral relativism of the created civilisation, which for a European, especially touched by the experience of war, was impossible to accept.

Obviously, America with all its naturalism and ahistoricity still tempted the poet. It seemed to assure protection from the tentacles of the past, the cruelty of the well-known game of History. The temptation of immersion into an uncomplicated rhythm of repeating seasons surfaces in Poetic Treatise very intensely. The tempting idyllic of an American farmer was however abandoned: 
Wiele nam będzie, wiele wypomniane

Żeśmy, tak mogąc, spokój odrzucili [...]

Milczenia marzeń o strukturze świata

Godnych szacunku. I że temat wieczny

Nas nie pociągał jak trzeba ni czystość

Że wręcz przeciwnie, pył zdarzeń i nazwisk

Chcieliśmy co dzień poruszać słowami [...]

[To us, much, many things will be reproached

That, being able to do it, we rejected the peace [...]

Silence of dreams about the world structure

Trustworthy. And that the eternal subject

Attracted us at it should have been neither the purity

That just in contrary, the dust of events and surnames

We wanted every day move with the words [...]]

"This is the matter of decision to leave America" - Miłosz said ${ }^{16}$. Whereas, the question: "Why in nature, hot as neon / For ever do not set a family" at this stage was decided unambiguously ${ }^{17}$. Despite the biological time, given to man, giving an actual meaning to life, historical time, "the only courtship of immortality, courtship of the human peculiarity in comparison with nature". Not only the gift but also a duty. In the meantime, "about Greece, about Greece who remembers here" - repeated the stanza in the poem Reminding. The poet searched for his place not on the continent but in a Europe humanly polluted by the history where a "butterfly stains the flowers with blood", and "a red poppy cut with rime of tears" - calling it "a sweet homeland". In Native Realm he clearly rejected the possibility of specifying the centre of settlement. It is neither Vilnius, Savoy nor Poland - but the whole European continent.

Did "saying goodbye to farm and rose" and turning to the universal, two thousand year old heritage of Greeks, enable him to see also in a new light the meaning of a return to Lithuanian, native roots? "Native realm was in me with its mountains, forests and capitals, and this emotional map blinded too much temporary problems"18. Lithuania seems to be involved in the trend of all the output of

${ }^{16}$ E. Czarnecka, Podróżny świata: Rozmowy z Czesławem Miłoszem. Komentarze, Wydawnictwo Literackie, Cracow 1992, p. 120.

${ }^{17}$ However, not only at this stage, because in further output he continuously came back to the questions about mutual relations between the elements of Nature and History, wordlessness and eternity. (See C. Miłosz, Kontynenty, Znak, Paris 1957, pp. 224-225: “[...] constant bending on one or another side, constant jumps from the historical position to 'eternal' and vice versa, with longing for such their connection find their proper extent, it was and it is for me the most important reason of worry").

${ }^{18}$ C. Miłosz, Rodzinna Europa, Wydawnictwo Literackie, Warsaw 1990, p. 310. 
our continent, however, while it does not play a significant role, a gradually critical attitude towards a provincial origin pulls back beyond the local perspective. Still in the poem there can be noticed a tone of uncertainty, vagueness about his place in the world. Karpiński noticed in Native Realm "an attitude of poor relative, ashamed of his tradition and not completely this shame masking"19. Though, despite constant searches and accepted points of view, the poet's situation expressed the term "knocked off his perch".

Significant for the collection The Light of Day, criticism towards his own past can be understood as the poet's question about the possibilities of human memory. Hostility towards the community of Polish emigration results from, among other, suspicion of distorting the truth under the influence of sentimental longings. The poet was aware of the memory's shortcomings, its transitoriness, unreliability and limits. That is why the first reaction is rejecting the past and in this way not submitting to the weaknesses of the muse Mnemosyne.

"Having left homeland do not turn away, Erinyes are following you" - after years exactly this saying will be chosen from Pythagoras's theories ${ }^{20}$. Nevertheless, it should be emphasized that memory is a sign of fidelity and loyalty towards those who are connected with the past, as well as the source of past reality distortions. Each challenges the purposefulness of returns to that which was, meaning of memories about people, places and times, all connected in Miłosz's poetry with various doubts and renunciations. They have found their literary echo, among others, in the poem Mother`s Grave:

Między pamięcią, która niepokoi

Bo mówi: na nic zwyciężać minione, I niepamięcią, która jest obrazą

Dla marnych pojęć o własnej dobroci Żyjemy chwiejni.
[Between the memory which worries because says: for nothing defeat the past, And oblivion which is an insult for poor notions of one's kindness We live uncertain]

The fidelity to the past for Teresa Żarnower, as the text The Spirit of the Laws gives bitter ascertaining, finished tragically. The painful memory of "dead friends, cities and rivers" will not change anything. It is only a "pine anchor in a sandy plain", it kills the joy of ordinary human events, intensifies the disaster and alienation of an individual. One cannot show it credibly and convincingly, thus it will not prevent the disasters of the future, even if shouts it to the world, thus in its name "tear the heart of the world off with a knife".

Just as in Antigone, the statement of Ismene - "Why to reach backwards?" - who the difficulty of silence acknowledges as a victory, opposes the one sister's

${ }^{19}$ W. Karpiński, Spotkanie w San Francisco, in: idem, W Central Parku, Libella, Paris 1982.

${ }^{20}$ C. Miłosz, Hymn o perle, Wydawnictwo Literackie, Cracow 1983, p. 35. 
deep conviction that a man deprived of memory does not deserve a complete contemporary life. Not until the awareness of involvement into the historic persistence of generations enables us to see unique phenomena in what is common and trivial; in typicality enables us to notice particularity. It is memory, also severe, which dissuades a man from the self-satisfaction and too easy solace - giving him a genuine dignity:

Głupcy są zdania, że kiedy poświęcą [The fools think that if they sacrifice Pamięć przeszłości, będą żyć szczęśliwi. The memory of the past, will live happily. I głupcy myślą: zgon jednego miasta Nie jest dla innych miast jeszcze And the fools think: decease of one city is not a sentence for other cities]

wyrokiem

William Blake in the I Milton compared a man to a wanderer, who each time he moves his seat, is accompanied by Heaven. And wherever he goes, he finds sunsets and sunrises and along with them his own place in the world ${ }^{21}$. Such an attitude is obviously tempting but at the same time one should assume that once we make our orientation in the space where we live (usually in youth), it is not easy to revise. Because of this reason Czesław Miłosz confided to Ewa Czarnecka: "My Lithuania's amputation is painful"22.

\section{Claim}

The sixties - as noticed by Wojciech Karpiński - increased the need of geographical-spatial detail situating the protagonist in Miłosz's poetry. In 1958, there appeared the essayistic Continents and Native Realm, and a few years later A View of San Francisco Bay. Images of Europe, America and Lithuania continuously collide. In this literary output the connections with the European culture are strongly heard, but also hints suggesting the attempts at settlement in America. However, everywhere Miłosz seemed to be accompanied by the sense of distance and coming from outside, outside from observed actual world. This distinctness - as he admitted - owed to his Eastern European and precisely Lithuanian origins ${ }^{23}$. In the collection The Light of a Day the negation of his Borderlands heritage was becoming stifled. As a result, the remembrance of beginning

${ }^{21}$ C. Miłosz, Ziemia Ulro, p. 189.

${ }^{22}$ E. Czarnecka, Podróżny świata..., p. 166.

${ }^{23}$ Miłosz described Lithuania as a "metaphor of coming from outside, that is an otherness and distance, which is enabled by otherness" (See C. Miłosz, Prywatne obowiqzki, Pojezierze, Olsztyn 1990, p. 64). 
did not disappear. More intensively, Miłosz poetry was filling with highlights from the Vilnius or Sztejna landscapes, multiplied images of his friends and colleagues, custom role-plays, colourful images of streets, squares, churches. One should note the commonly acknowledged psychological view that our imagination develops first of all up to twenty-five, then we accept and absorb which reminds us of well-known things, which can be a peculiar mental reproduction. The question "How one can forget?" - rings out in one of Miłosz poems. The poet confided to Ewa Czarnecka: "In connection to the stay in California the need of settlement in the history, in a place, the whole past of such a place is increasing" 24 .

Memories of an emigrant will not restore the sense of order, will not move the poet to a dream of a land of normality. The poetry of Miłosz is penetrated too much by the awareness of eternal wandering, eternal ban of return:

I nigdy już nie uklęknę nad rzeką w maleńkim kraju żeby co we mnie kamienne rozwiązało się $[\ldots]$

(Gdzie wschodzi stońce i kędy zapada)

[And ever I won't kneel by the river in the tiny land to which was stony would be solved [...]]

(When the sun rises and when it sets)

Natural in that case is the rejection of the Arcadian perception of the childhood land, even more so because the exile is marked not only with the decision of leaving his homeland but also with a painful historical-political loss of "precise homeland". Created after the Second World War, the Lithuanian Republic, a part the USRR, and then independent Lithuanian, do not have much in common with the Polish Borderlands - an area of luxuriant nature, a borderland of cultures, religious or ethnic mosaic. Foreign country, foreign cities, Wilno changed into Vilnius - although externally it was not changed. That was probably why also Miłosz very often emphasized his dislike for visiting Lithuania after many years of absence:

Gminy zapadłe po osie, nazwy dla nikogo prócz mnie: Ginejty, Jas wojnie, Opitołki.

(Na trabach i cytrze)

[Communities desolated up to the axles, names for nobody despite me: the Ginejts, John on war, Opitołki.]

(On trumpet and zither)

${ }^{24}$ E. Czarnecka, Podróżny świata ..., p. 166. 
And for the outcast who rejected idealizing and simplifying the past, but also was aware of the impossibility of "amputating" it, a new problem appeared - of saving poetry in a dying, razed world. How can it be preserved, kept in memory, the images of the Land of Lake going by with the swift waters of a Heraclitean river, its culture and habits?

"How can it be forgotten?" - the poet asked and immediately gave the answer: "however, you can forget". Time muffles the sense of the past, erases emotions. In Elegy to N.N the loss is understood more and more indifferently, "and heart doesn't die when, it would seem, it should". Only details remain in the memory, the least important things - images of dogs, Maruszewski's hunting near the Klejwa forest, a canoe trip to the Gaładuś lake - small events, for unknown reasons distinguished by Muse Mnemosine, "the book of colours and gloss, tastes and fragrances", which only by coincidence happened to this but not another man. It is called the "logic of the ashes" because as the ash covers the clear image of human life, falls on its significant meaning:

Dlaczego, skąd i po co nie odgadnąć. "Why, where and what for not to guess" (Elegia do N.N) (Elegy to N.N)

As the author of Moral Treatise could preclude the past, the most important task became the attempt at understanding the chaos of signs, an attempt at ordering what was passed in the presence:

Ale żeby to dawne było do zniesienia, But so that the old days were supportable żeby dzień, rok zaczynać, jakaż praca! So that day, year start, what a work! Jaki zamknięty w sobie, nieużyty człowiek. Such a reserved, awkward man (Jak można zapomnieć) (How one can forget)

It is an assertion of a certain status quo, the persona in Miłosz's poetry. $\mathrm{He}$ must break through the incomprehensible course of details constantly from the beginning just to find his tone, his "great misère". Perhaps it is the reason, among others, of the spiritual development, about which - commenting in the previous collection - Gombrowicz wrote: "Miłosz, no: There isn't a history that would replace your own awareness, maturity, depths, nothing will absolve your from yourself. If you are personally important, even moving to the most conservative place in the globe, your witness about your life won't be valid; but none historic laundry press will impress the words more important from immature people"25.

Just building maturity required constant getting used to, in a fight with failing memory, to its roots, values protected from falling into Non-being.

\footnotetext{
${ }^{25}$ W. Gombrowicz, Dzienniki..., p. 92.
} 
I jakże dogonisz mnie, uroczysta, odważająca winy i zasługi, jeżeli nie pamiętam kim jestem i kim byłem?

[And how would you catch up with me, solemn, weighting out the faults and merits, if I don't remmember who I am and who I was?]

Thus, the past does not terrify, on the contrary, its rejection can threaten us with loss in the world and being deprived of our identity. The logic of ash, confusion - it would seem - controlling the memory of accidental details causes fear but also provokes us to search for ways to tame the darkness of Non-being. "Attached to each the tiniest sign of being - Aleksander Fiuto wrote about Miłosz - does not want to accede to its depletion even in the sacred dimension" ${ }^{26}$. In the meantime, even the most scrupulous way of showing the past, something will always be omitted or transformed, on the basis of experiences and awareness of maturity. Only those, who crossed to another side of the world have a chance to touch the false past because they are completely immersed in done reality:

I Jakub Jasiński porozumiewa się jak umie z Lilian Gish, gwiazdą filmu.

[And Jakub Jasiński communicates as he can with Lilian Gish, a film star,]

"When we experience something, it seems to us as it was such and then it appears to be different" - the poet said on the margin of the poem Language was changing - "For us, it is difficult to catch the thing which concerned that perception, that experience. But what now is shaping into story, it is distant. Where is this truly real? Neither then, as we experienced it, nor now as we are shaping it into words." 27

Passing time intensifies the nonuniformity of the language towards concrete experiences and imperfections of memory destroying the sense of full being. However, it is a source of creative distance, which Simone Weil specified as the "soul of the beauty":

Kontemplacja czasu jest kluczem do życia ludzkiego. Jest to niesprowadzalna do niczego tajemnica, do której żadna nauka nie ma dostępu.

[Contemplation of time is a key to human life. It is an unreducible to nothing mystery, which none of the science has access to]

\footnotetext{
${ }^{26}$ A. Fiut, Moment wieczny. O poezji Czesława Miłosza, Open, Cracow 1993, p. 111.

${ }^{27}$ E. Czarnecka, Podróżny świata ..., p. 139.
} 
Distance enables us to understand the uniqueness of details, call them - and in this way immortalize, into being without a beginning or the end. It is a way of showing all the experiences connected with his Lithuanian childhood and youth in the cycle of poems On trumpet and zither:

Mokre trawy żyznych dorzeczy odjęły mi czas i zmieniły wszystko w teraz bez początku i końca.

[Wet grasses of fertile river-basins took my time and changed

Everything in it without beginning and end.]

Not only do things develop new virtue but also a man has an opportunity to immerse himself simultaneously in the past and present, to be mature without throwing away the child's nature. In the poem What was great on the boy's face floating the boats made of tree bark, overlapping the adult's face, a child with an Indian bow, described in Gucio Enchanted, suddenly becomes a man, and a girl - an elder woman. In one of his essays Miłosz cited Kierkegaard who saw the meaning of life in overcoming the limits of the time given to man and disturbing its typical, chronological order. "Being young and then getting older and finally dying - it is a miserable form of human existence, this merit has each animal. Whereas combining different stages of life in one synchronicity is a task which faces human beings" 28 . The one who cuts the ties of childhood, the philosopher bluntly called a good-for-nothing.

Returning to his Borderlands childhood and youth, acknowledging this stage as an equal in comparison with the experiences connected with the constant, even magical process of "breaking the spell". Seized and written down details, persons or events become clearer, start leading their own lives, create new internal life based on a well-known Lithuanian reality. Ostensibly incomprehensible and accidental seems to reflect the metaphysical order of being:

Kiedy księżyc i spacerują kobiety w kwiaciastych sukniach zdumiewają mnie ich oczy, rzęsy i całe urządzenie świata.

(Kiedy księżyc)

[When there is a moon and women are walking in flowery dresses

I am amazed with their eyes, lashes and the whole order of the world,]

"Seeing does not mean to have in front of your eyes" - Miłosz said in 1981 accepting the Nobel Prize - "it means also to preserve in memory, 'see and describe'

${ }^{28}$ C. Miłosz, Ziemia jako raj, in: idem, Ogród nauk, Wydawnictwo KUL, Lublin 1986, p. 44. 
means to reproduce in imagination" 29 . From such a point of view Vilnius is shown in the last excerpt of City without a Name. To the Lithuanian capital, known to the poet from his own experience, one cannot return and compare the preserved images with the present. "Distance which makes the mystery of time" - the poet went on his Stockholm lecture - "does not have to change events, landscapes, people's faces into an entanglement of becoming more and more pale shadows. Contrary, he can show them in full light that is each fact becomes expressed and lasts for the eternal reminding of human unlawfulness but also a human greatness. Those, who are alive, are given a mandate from those who are silence forever."

An exceptional receiver of the mandate from the world passing away towards eternity is a persona of the mentioned excerpt:

Czemu już tylko mnie powierza się to miasto bezbronne i czyste jak naszyjnik weselny zapomnianego plemienia?

[Why am I only entrusted this helpless and pure city

As a wedding collar of the forgotten tribe?]

The forgotten city of the forgotten tribe, immersed into no-time:

Tutaj nie ma wcześniej i nie ma później, wszystkie pory dnia i roku trwają równocześnie

[Here there isn't earlier or later, every day's and Year's time last simultaneously]

- is compared to the settlements of Native Americans whose past life is shown only by the signs on stones or the remains of buildings - dead, waiting for "neck and foregad" without success. The poet tried to rebuilt this lost fervour in his recollections of Vilnius. The poet recalled concrete streets - Nadbrzeżna, Niemiecka, Arsenalska - church interiors, squares, known and unknown persons, as even the owner of accessories shop, Barbara Żałobnica. Everything demands to be confirmed, calls the narrator to give the witness about the past, "because nobody despite me does not know that once they were alive". The city seems to be subjected to "purification", details become clear, receive the new local colour and perspective. With randomness they are following towards order and purposefulness. Vilnius " $[\ldots]$ is standing in front of me, there are all of the some from chimneys, echoes, when I am crossing the rivers dividing us". In The Unencompassed Earth this phenomenon was described by Miłosz himself:

${ }^{29}$ C. Miłosz, Zaczynając od moich ulic, Instytut Literacki, Paris 1983, p. 356. 
Jakby zamiast oczu wprawiono odwróconą lunetę, świat oddala się i wszystko, ludzie, drzewa, ulice, maleje, ale nic a nic nie traci na wyrazistości, zagęszcza się.

(Stan poetycki)

As if instead of eyes one had put in an reversed telescope, the world is going away and everything, people, trees, are decreasing but nothing loses its expressiveness, is thickening.

\section{(Poetic State)}

On the one hand, the connection between the persona and the world which is being shown is taking shape - a mission of extracting from "throat of movement" the passing phenomenon, people and places bear a name of "donation", "entrustment"; on the other, it is obvious that the distance accompanies the view of Vilnius. The freshness and naivety of childish perception become entangled with a bitter conviction about the obtuseness of human memory and perception skills:
Z jakąż to wielką wiedzą skręcam w Arsenalską i raz jeszcze otwieram oczy na daremny koniec świata?
Przez pokoje z szelestem jedwabi, jeden, drugi, dziesiąty, biegłem nie zatrzymany, bo wierzyłem w ostatnie drzwi.
Ale wykrój ust i jabłko, i kwiat przypięty do sukni były wszystkim, co poznać i wziąć było dane.

[With such a great knowledge I am turning into Arsenalska and once more I am opening my eyes for the futile end of the world?

Through rooms with rustle of silk, first, second, tenth, I was running Without being stopped because I believed in the last doors.

But the shape of lips and an apple, and a flower pinned to dress were everything, Which were given to be known and taken ${ }^{30}$.]

The return to Vilnius is connected with an attempt at enlivening the forgotten city, but at the same time an attempt at dominating its own going by. How it is possible, this connection, the integration of various stages of the narrator's biography, when it seems that Vilnius stopped in time could be saved from Heraclite's river. However, it is an illusory impression. The poet emphasized that about fidelity, to which he felt obliged, one can speak only in the terms of literary creation. What is more, the memory has not only the ability of mimetically repeating the events that

\footnotetext{
${ }^{30}$ It was expressed by Miłosz even though in Dictionary...: "if I am saying now what was seen, because I should warn that I am there at the same time and as a small boy, as a juvenile, as an adult, so many years of watching becomes shortened to one moment" (see: ibidem, p. 11).
} 
once took place but also the power of building based on past events and places of new dimension. The thing, which happened, would never be the same:

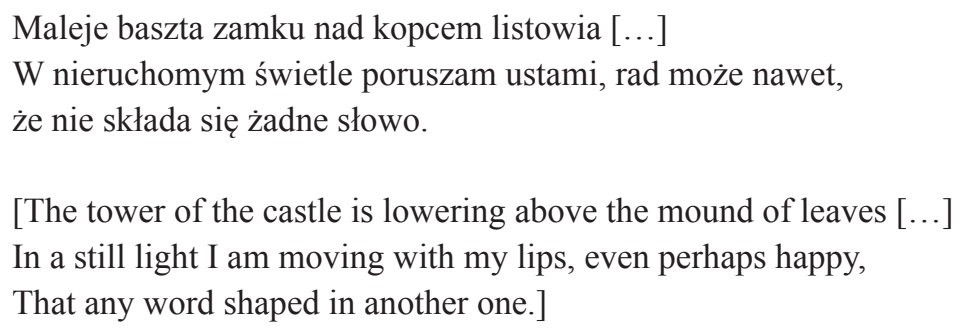

The gradual transition - in the poetical visions of Lithuania - happens from portraying specific places and people to organizing them from the remains of the real internal world. According to Heidegger's philosophy existing means being in the world which is a part of our "ego" which intervenes deeply in our life, integrates together and gives it a proper face. However, being in the world means also to inhabit it creatively. For this process Heidegger used the term "building"

About such a building in the sphere of spirit with the simultaneous preserving connection with external reality, one could say à propos the output of Miłosz. For this reason, all the mentioned cycles bear a meaningful title: City without a Name, as the fight wager not about with time but a specific spirit of this space and its internal order. The poet should not close in present but overcome it, managing formerly known areas in a new way. It is a fight indeed:

Kto honorować będzie miasto bez imienia

kiedy jedni umarli, inni płuczą złoto albo handlują bronią w oddaleniu od kraju
[Who will honour the city without a name

when ones will be dead, other rinse the gold or trade with guns far away from the country.]

The city without a name - because it is deprived of the remembrance of its children, pulled out from its geographical stabilisation on Earth and first of all shaped by the world of human culture, history and tradition. Revealing this exceptional genius loci radiating on different areas, centuries and representing them people.

Crossing the borders very often we become aware suddenly of the distinctiveness of countries and cities, we feel the differences between the English pub, French cafe, Vilnius street, and Warsaw Old Town. "Unique character of the geo-

${ }^{31}$ M. Heidegger, Budować, mieszkać, myśleć. Eseje wybrane, K. Michalski (ed.), Czytelnik, Warsaw 1977. 
graphical places cannot be reduced to the geology, topography and occurring in a certain region climate, neither to genetics, economy, nor politics" - René Dubos wrote in Praise of diversity ${ }^{32}$. Also, Mitosz considered the reasons for Vilnius' uniqueness and especially its fascinating cultural prolificity:

Gdzie szukać źródeł? W architekturze? W kościołach i świątyniach różnych wyznań? W rozlegającej się na ulicach mieszaninie języków? W rozmnożonych lożach masońskich? W murach uniwersytetu, tak różnego od innych ówczesnych polskich uniwersytetów? Czy też po prostu w „aurze” gdzieś z początków XIX stulecia? Dlaczego, beznadziejnie prowincjonalni, byliśmy jednak mniej prowincjonalni niż gdzie indziej wychowani nasi rówieśnicy, bardziej otwarci na „innych” czy „międzynarodowi”?

[Where should one look for the sources? In architecture? In churches and temples of different religions? In spreading along the streets mixture if languages? In multiplies masonic lodges? Behind the walls of University, so different from others Polish universities? Or just in the "atmosphere" of the beginnings of the $19^{\text {th }}$ century? Why, miserably provincial, we were however less provincial than our peers brought up somewhere else, more open for "others" or "international" ${ }^{33}$ ]

The whole city without a name becomes a peculiar community of ages, interlarding times and people and generations' experiences, a place immersed in tradition and culture. Thus, in the space there will not be Californian sun and the desolation of Death Valley, deprived of the necessary stocks with time, invariably with its natural order, contrary to the efforts of human memory in this way. Once more, in Miłosz poetry biological time is compared with the time of human history:

W Dolinie Śmierci myślałem o sposobach upinania włosów

O ręce która przesuwała reflektory na studenckim balu

W mieście skąd żaden głos już nie dosięga

Minerały na sąd nie trąbiły

Osypywało się z szelestem ziarnko lawy.

[In Death Valley I thought about ways of pinning up hear

About a hand which had been moving the searchlights in a students' party

In a city where none of voices comes to

Minerals did not blow at the court

The coffee ban was pouring rustling.]

${ }^{32}$ R. Dubos, Pochwala różnorodności, transl. E. Krasińska, PIW, Warsaw 1986, p. 11.

${ }^{33}$ C. Miłosz, Język, narody, p. 132. 
Nevertheless, the images of past centuries last long - even the epoch of Napoleon and Metternich or the person of the librarian Kontrym watching the deeds of Great Army from the window of Poczybut. The tower, inside of which the $18^{\text {th }}$ century observatory was situated, had a beautiful baroque facade, patterned with painted signs of the zodiac and the Latin proverb of Virgil: "The courage lights the old world with a new light". With such courage the Philomats stepped in parades and one hundred years later the Creative Original Section of Polish Philologists and in 1821 Mickiewicz, in 1929 Miłosz. Those parades were obviously genuine but they could be treated as symbolic, common for all the generations' journey towards the darkness of eternal oblivion. Vilnius of the $19^{\text {th }}$ century and the city of the poet's youth were subjected to the same laws of time, they encountered an identical fortune:

A książek tośmy całą bibliotekę napisali [We wrote the whole library of books

A krain tośmy co niemiara zjeździli We travelled through countries without any limit

Bitew dużośmy, dużo przegrali

We lost many battles

Aż i nie ma, ni nas ni Maryli.

Neither we are nor Maryla]

The parade of the centuries in the city without a name is enriched by visions: the lodge of the fervent Lithuanians - the genuine Masonic lodge, a famous fair called Kaziuk - as it took place on the day of Lithuania's patron saint, meetings after mass in the Basilian church, the entire chaos of everyday life, its bluntness, fragrances and local colour. All these images pass around the experiences most certainly human, that is short-term, falling into nothingness. Not without a reason, some excerpts of the cycle refer to literary motives of Baroque, dominating in Vilnius landscape and atmosphere, to the idea of "vanitas vanitatis":

Z paznokci, śluzowej błony

kiszek i płuc, i śledziony

Czyj dom będzie uczyniony?

Swój własny a jeden z wiela

Nie mam w sobie przyjaciela,

Czas mnie na dwoje rozdziela
[Of nails, mucous membrane appendixes and lungs, and spleen

Whose house will be built?

One's own and one of many

I don't a friend in me,

Time divides me in two]

The attempts at liberating the Vilnius world from the threats of Nothingness very often disappoint. "Nothing includes the gestures, a hard stone". Individual memory does not cope with a new space, does not dominate it completely. That is why entrusting the city without a name to the persona meets with his fear, mercy for himself, for his helplessness and ignorance: 
Czym zasłużyłem, jakim złem we mnie, jaką litością, na to ofiarowanie?

[What have I deserved, which evil in me, which mercy, for this offering?]

Not only the time passing but the unreliability of memory intensifies this feeling of non-fulfilment but also conviction of guilt towards the dead for whom the narrator mandated:

A już tebańskie świeczniki lokaje wnieśli

I na oknach zasuwali za zasłoną zasłonę

A kiedy zdejmując rękawice pomyślałem że wszedłem pierwszy,

Zobaczyłem że wszystkie oczy są na mnie zwrócone.

[And footmen have already brought the Theban candlestick

And in windows they were drawing the curtains one after another

When taking the gloves off I thought that I had entered first,

I saw that all the eyes were upon me.]

What do the Theban candlesticks brought by the footmen mean? Indeed, the romantic atmosphere is not only typical for freemason celebrations, although it would be justifiable in this excerpt, as an announcement of entrance into the sphere of mysticism. They can be also a sign of comparing Vilnius to a wonderful harp, after which the ruins remained. The light - a symbol of eternal and spiritual life - leads gradually through centuries, up to the human space. From there this is a call to fidelity to the dying world, it is from there that leads the way to the mediumship of Miłosz's poetry:

Może Anna i Dorcia Drużyno wezwały mnie z trzechsetnej mili Arizony, bo nikt prócz mnie już nie wie, że raz kiedyś żyły.

[Perhaps Anna and Dorcia Drużyno called me from the three hundredth mile of Arizona, Because nobody despite me knows that once they lived.]

The conviction about the possibility of creative coexistence of the past and present becomes more and more prominent thanks to the enrichment of individual memory - with a collective awareness of tradition and culture. Was the development of Tomasz in Issa Valley not shown in a similar way:

Nikt nie żyje sam: rozmawia z tymi, co przeminęli, ich życie w niego się wciela, wstępuje po stopniach i zwiedza idąc ich śladem zakątki domu historii. Z ich nadziei i przegranej, ze znaków, jakie po nich zostały, choćby to była jedna litera wykuta 
w kamieniu, rodzi się spokój i powściągliwość w wypowiadaniu sądu o sobie. Dane jest wielkie szczęście tym, co umieją je zdobyć. Nigdy i nigdzie nie czują się bezdomni, wspiera ich pamięć o wszystkich dążących jak oni do nieosiągalnego celu. Tomasz zdobyć miał kiedyś to szczęście albo nie, w każdym razie, chwile jak ta z dziadkiem trwały w nim, wzywając wieku, w którym głosy przytłumione przez odległość stają się cenne.

[Nobody lives alone: talk with those who passed away, their life impersonates it, Steps and visits following them the corners of the house of history. From their hope and loss, signs which remained after them, even if it was one letter forged in stone, rises the peace and restraint in pronouncing the judgement about itself. It is given a great happiness to those, who can acquire it. Never and nowhere they do or feel homeless, they are supported by the remembrance of everybody striving for the unreachable goal as they do. Tomasz was about to acquire this happiness one day or not, anyway the moments as such with grandfather lasted in him, calling the century, when voices muffled with the distance become precious ${ }^{34}$.]

The city without a name moves us in the sphere of the past harmonising with the present, where the witness of community has the power of keeping what passed and combining it with the present. Everything was harnessed in a universal rhythm. The Borderlands become an unreal country, still culturally developing and constantly gathering new people. It does not mean being saved definitely from extermination, because the conviction of literary creation - as I have already written - is very deep. In this way, the credibility of the internal space of the city without a name becomes questioned. How to overcome this questioning? - it is not possible to live in chaos. Perhaps, one should look for the answers in penetrating the poem When the sun rises and sets is belief in apocatastasis. The world is saved in its most significant cultural and community values not only through its transfer in a new symbolic dimension but thanks to complete thesis, religious sanctioning.

The title of the poem When the sun rises and sets, taken from the fiftieth psalm, defines the audience (that is all the Earth's habitants), and the comments on the situation of the narrator who is subjected to constant transformations:

Cokolwiek dostanę do ręki, rylec, trzcinę, gęsie pióro, długopis,

Gdziekolwiek odnajdą mnie, na taflach atrium, w celi klasztornej w sali przed portretem króla

Spełniam, do czego zostałem w prowincjach wezwany.

\footnotetext{
${ }^{34}$ C. Miłosz, Dolina Issy, Wydawnictwo Literackie, Cracow 1989, p. 99.
} 
[Whatever I will be given to my hand, stylus, cane, quill, pen,

Wherever they will find me, in the sheets of atrium, in a monastic cells in a chamber in front of king's portrait

I fulfil, which I was call in the province for.]

Though in City without a Name the motif of entrusting Vilnius to the poet is clear, he did not have such a resounding call to fidelity in the poem, even against will:

Czyż ten ma zostać wiemy, kto nie chciał być wierny?

[Should also become faithful, who didn`t want to be faithful?]

One persona combines the incarnations of the creator from different centuries and places. The Narrator seems to be omnipresent, constantly changing masks, centuries, surroundings. He is an emigrant, almost identical with the internal author, settled at the shore of the Pacific and removed from his homeland. Several verses later he changes into an old poet contemplating family archives and engrossed in reading the Lithuanian Encyclopaedia. At the same time, this point of view covers the child's glance, dreaming among Kaunas's forests with an abundant nature of America. He appears also as a twentyyear-old youth and poetical initiation, centre of generation of the experiences of the years 1910-1915.

There is also a pilgrim, wandering through countries in search of order and harmony. He is characterised by relentlessness and the patience of a romantic wanderer, combined with a painful knowledge of a lost goal in the twentieth world "aiming at passing".

Here and there the personal narrator gives up his independence and says in the name of his peers' community, maturing in the atmosphere of Vilnius culture.

The variety of created masks accompanies also a multitude of recalled protagonists. Friends populate this extraordinary space such as Teodor Bujnicki, professors and people of outstanding merit for Lithuania - Father Jucewicz, Marian Massonius, Stefan Bagiński, acquaintances - Elżbieta, Sir Hieronim and various accidental people whose individual experiences are confirmed by the notes in archives, documents, literature or memories. Mentioned by name are only a circle of a chosen few from among many. The land based on the community of centuries, ceremonies, traditions, poetry (which was also analysed precisely by J. Dudek, showing numerous literature references - to The Bible, Baroque literature or folklore) is rich ${ }^{35}$.

${ }^{35}$ J. Dudek, "Gdzie wschodzi słońce i kędy zapada". Europejskie korzenie poezji Czesława Miłosza, Nakł. Uniwersytetu Jagiellońskiego, Cracow 1991. 
Not only the personas or times change in the poem but also places. It is possible to notice at least several outlined spatial centres. On the one hand, there is Lithuania and especially the places of careless childhood at Nieważ and Vilnius of youth experiences. On the other, French landscapes, especially La Dordogne, which Miłosz defined as "it is one of the most beautiful places in the world" ${ }^{36}$, accompanies the landscapes of California where the mature life takes place.

How one can find home among these surroundings, time and people? Intensity threatens with disorder, disturbs a clear, ordered world, questions the sensibility of its own present. Lost generations, cities, habits and traditions look for an anchoring, a point of support releasing from waste the heritage of Urizen.

"Imagination" - the poet claimed in A View of San Francisco Bay - "doesn't accept the general dispersion, without any single Place, which others are referred to" ${ }^{37}$. That is why all the mentioned elements of the known and experienced world are included in a peculiar, common dimension, combining times and areas, Upper-Land, in reality "already perfect". However, as it could be safely called the spatial centre, there is a need of something more than reconstructing the past, its interiorising - there must occur an "undoing", restoring all the moments in their pure forms, so sanctioned religiously. Hence, one of the essential terms in the poem is, occurring in the seventh part entitled "Bells in winter", the term apocatastasis:

Zdawałoby się, nie widać powodu

Skoro odjechałem znacznie dalej

Niż jakiekolwiek drogi przez góry i lasy,

żeby tutaj przypominać tamten pokój

Należę jednak do tych, którzy wierzą w apokatastasis

[...] Znaczy: przywrócenie. Tak wierzyli Święty Grzegorz z Nyssy,

Johannes Scotus Erigena, Rnysbroeck i William Blake.

Każda rzecz ma więc dla mnie podwójne trwanie

I w czasie i kiedy czasu już nie będzie

[It would seem that there is no reason

As I went further

Than from any way through mountains and forests,

To recall here that room

However, I belong to those who believe in apocatastasis

[...] It means: restoration. In this way believed Saint Gregory from Nyssam

Johannes Scotus Erigena, Rnysbroeck and William Blake.

${ }^{36}$ E. Czarnecka, Podróżny świata..., p. 166.

${ }^{37}$ C. Miłosz, Widzenia nad zatoka San Francisco, Wydawnictwo Literackie, Cracow 1989, p. 29. 
So, each thing has for me double lasting

In time and when the time is over.]

The term apocatastasis, taken from the New Testament, restores magical Power to a word in Miłosz's poetry. It is not the fidelity of memory that becomes important but naming details. The isolation of things, people, moments undertake the process of purifying from the flow of life, thus crossing the river Lethe they do not die but remain restored to the new reality. What is more their existence is fuller than before. It is only with this magical life beyond both present and future time based on the feeling of Transcendence that creates a special space, a purely spiritual one, an eternal one, not prone to oblivion or the passage of time. In a poem Gdzie wschodzi stońce i kędy zapada (Where the Sun rises and sets) it is called Lauda.

It is a land - as prologue says - of which one eminent alchemist once wrote that it is where our first and most important of our mind's needs puts it, the very same need that gave life to geometry and science, philosophy and religion, morality and art. It is also - as this alchemist and an ally of Descartes wrote - that the name of this land can be Saana or Armageddon, Patmos or Lethe, Arcadia or Parnassus.

Despite the levelling of the above-mentioned places each of them carries different meanings. The Muslim land of Saana as the only one that equals European Arcadia. They are fundamental places of eternal joy. Armageddon suggests such an idyll announcing the final battle between Good and Evil after which God will ultimately take Earth as His dominion. Patmos is a symbol of religious revelation, as it is the place where the Apocalypse of St John was created, Lethe is the river of oblivion. Parnassus is a name from Greek Mythology - a mountain where the most famous seat of poetry and music was located. In this context, Lauda is an extraordinary land - it combines in itself a myth of absolute happiness and oblivion, a myth of exile, gathering within its boundaries powers of religious experiences and metaphysical fights of Light and Darkness, with all the power opposing the emptiness of the Ulro land. It has the right to over-idolize everything that appears within its boundaries, keeping it and giving sense to what was, is and will be between the sunrise and sunset of the world.

In this land yesterday's events and those 400 years old differ a little only. The place is different as it gains, does not lose, its expressiveness is concrete and remembering it I shun any making up. Despite the fact that I received the images of earth in many countries on two continents my imagination could not cope with them any other than setting them a place in the South, in the North, in the East and in the West of the trees and hills of one district. 
What is the reason, it could be worth asking, that the most realistic districts such as - Kiejdany and Kowno - were raised to the rank of magical space, the enhanced one, that they start gathering in themselves landscapes from other parts of the world, known in a mature life things, people, events that effectively protect from Nothingness?

Does it result from the fact of a peculiar role of childhood and the land of youth for every man? Maybe it was the history of Lithuania that turned out to has been decisive as well as its culture creating role in Polish literature?

Other peculiar features of this land can also exert their influence, such as the gentleness of the climate, nobility and the originality of the people, close connection with the past and tradition. But the most important one - I think - of its specific features is the building of deep interpersonal ties:

One must be thankful - Miłosz states in Prywatne obowiazki / Private duties - for what was given to us in the part of Europe that was neither from XIX nor from XX century. We couldn't appreciate this - only later were we able to do so observing people who never knew the warmth of organic bonds and try to warm themselves traveling to Solomon Islands in vain or to godforsaken Mexican villages ${ }^{38}$.

It is especially the ceremony that connects people and teaches them the compromises necessary to help the community avoid the traps of a selfish "ego". Thus, it draws people closer to Transcendence preparing to choose the world of values:

And now we are connected in the ceremony

in the crystal? In amber? playing music,

Neither that what was nor what will be.

Only that which is when the world reaches its end.

Lauda may have been born from the rebellion against the spiritual emptiness of Urizen, against a hopeless lay limiting of human life spaces. It is not without reason that Miłosz emphasized in his essays a characteristic mysticism of Lithuania, the knowledge and religious sensitiveness gained here that are the support in the journey, in instinctive "pulling out" of the soul from the barren land of Ulro.

How to manage without an own house in the land of Ulro? Man must live somewhere and the roof in the physical meaning is not enough as his mind needs points of reference and orientation, vertical and horizontal ones ${ }^{39}$.

\footnotetext{
${ }^{38}$ C. Miłosz, Prywatne obowiazki, p. 139.

${ }^{39}$ C. Miłosz, Ziemia Ulro, p. 132.
} 
It also needs the world of values, the space within which the awareness of culture and tradition is built, the experiences of generations and common faith thanks to which Homo viator can find Hominem Ritualem inside oneself.

Gradually, starting with a simple acceptance of Borderlands heritage through attempts of saving elements of the world from destruction by the passage of time, Miłosz's poetry evolves to a vision of Lithuania as an Over-Land situated symbolically between Sunrise and Sunset and being the opposition of Land of Ulro.

\section{Bibliography}

Czesława Milosza autoportret przekorny, interviewed by A. Fiut, Wydawnictwo Literackie, Cracow 1988.

Gorczyńska Renata (Czarnecka Ewa), Podróżny świata. Rozmowy z Czesławem Miłoszem.Komentarze, Wydawnictwo Literackie, Cracow 1992.

Dudek Jolanta, "Gdzie wschodzi słońce i kędy zapada". Europejskie korzenie poezji Czesława Miłosza, Nakł. Uniwersytetu Jagiellońskiego, Cracow 1991.

Fiut Aleksander, Moment wieczny. O poezji Czesława Miłosza, Open, Cracow 1993.

Gombrowicz Witold, Dzienniki 1953-1956, Wydawnictwo Literackie, Cracow 1989.

Heidegger Martin, Budować, mieszkać, myśleć. Eseje wybrane, Krzysztof Michalski (ed.), Czytelnik, Warsaw 1977.

Karpiński Wojciech, Spotkanie w San Francisco, in: idem, W Central Parku, Libella, Paryż 1982.

Kowalczykowa Alina, Wileńskie fascynacje, czyli o barokowej młodości Juliusza Stowackiego,

"Ruch Literacki" 1988, issue 6 (171), pp. 402-414.

Król Marcin, Podróż romantyczna, Libella, Paryż 1986.

Miłosz Czesław, Widzenia nad zatoka San Francisco, Wydawnictwo Literackie, Cracow 1989.

Miłosz Czesław, Dolina Issy, Wydawnictwo Literackie, Cracow 1989.

Miłosz Czesław, Ogród nauk, Wydawnictwo KUL, Lublin 1986.

Miłosz Czesław, Zaczynając od moich ulic, Instytut Literacki, Wroclaw 1990.

Miłosz Czesław, Hymn o perle, Wydawnictwo Literackie, Cracow 1983.

Miłosz Czesław, Prywatne obowiazki, Pojezierze, Olsztyn 1990.

Miłosz Czesław, Kontynenty, Znak, Cracow 2001.

Miłosz Czesław, Rodzinna Europa, Wydawnictwo Literackie, Cracow 2001.

Miłosz Czesław Ziemia Ulro, PIW, Warsaw 1982.

Miłosz Czesław Świadectwo poezji, Czytelnik, Warsaw 1987.

Miłosz Czesław, Szukanie ojczyzny, Znak, Cracow 1992.

Miłosz Czesław, La Combe [przedmowa do: S. Vincenz, Po stronie pamięci], Instytut Literacki, Paryż 1965.

Wachowicz Barbara, Ty jesteś jak zdrowie, Rytm, Warsaw 1993. 
Maria Berkan-Jabłońska

Poetic Lithuania of Milosz

(Summary)

The article deals with the images of Lithuania found in Czesław Miłosz's poetry. The novels and essays have only been used to confirm the conclusions drawn from the interpretation of selected poems. Despite the frequently-declared unwillingness of the author of Dolina Issy (The Valley of the Issa) to accept and use any autobiographical elements in literature, the land of his childhood has always been present in all the poet's works. The explanation of this fascination with nostalgia seems to be unsatisfactory. The author of the article perceives the poetic images of Lithuania created by the uprooted immigrant as a symbol of his inner, not purely geographical, settlement. The subject of the discussion is the ever-changing perception of the Eastern-Borderland, which corresponds to particular stages of the protagonist's journey through life. The starting point is the experience of eviction. It modifies the originally idealized vision of the "little homeland" and makes the hero's attempt to reject or "amputate" it. The poems from the Światlo dzienne (Daylight) collection surprise the reader by a hostile attitude towards the poet's youth spent in Lithuania and the perception of those early memories as some destructive forces threatening the artist. It is only after a many years' quest that the borderland heritage is appreciated and conquered again. Now, however, it acquires a different, more symbolic form. The cycle Miasto bez imienia (A Town without a Name) and the poem Gdzie wschodzi stonce i kędy zapada (Where the Sun Rises and Sets) are evidence of a gradual transformation. The faithful recreation in the poet's memory of particular places and people changes into the construction of some outside religious space, built from the traces of the real world. Lithuania changes into a perfect reality, a Super-Land, capable of retaining the past and combining it with the present. It is a prop freeing the poet from the waste land of Urizen

Keywords: Czesław Miłosz, poetry, poetic images of Lithuania 